\title{
Brief Report: Peculiar Evolution of Autistic Behaviors in Two Unrelated Children with Brachidactyly-Mental Retardation Syndrome
}

\author{
Luigi Mazzone $\cdot$ Lia Vassena $\cdot$ Liliana Ruta • \\ Diego Mugno $\cdot$ Ornella Galesi $\cdot$ Marco Fichera
}

Published online: 6 January 2012

(C) Springer Science+Business Media, LLC 2012

\begin{abstract}
Brachidactyly-Mental Retardation (BDMR) Syndrome (MIM 600430) is associated with terminal deletions at chromosome $2 \mathrm{q} 37$ and a limited number of studies also reported an association between 2 q $37 \rightarrow$ qter deletion and autism. Herein we describe two cases of autism in unrelated children with BDMR Syndrome, showing physical, cognitive, behavioral, and disease natural history homologies, with a very prominent social impairment in the first 4 years of life. At follow-up evaluations, spanning a 5-years period, both children experienced a progressive reduction of the autistic symptoms, besides retaining compromised cognitive ability. This report supports the hypothesis that genes in the $2 \mathrm{q} 37$ region may contribute to the etiology of autism, leading, however, to a peculiar evolution of the disease, with symptoms severity decreasing over time.
\end{abstract}

Keywords Autism $\cdot 2 \mathrm{q} 37$ region $\cdot$ BDMR .

Evolutionary course

L. Mazzone $(\bowtie) \cdot$ L. Ruta $\cdot$ D. Mugno

Division of Child Neurology and Psychiatry, Department of Pediatrics, University of Catania, Via S. Sofia, 78, 95123

Catania, Italy

e-mail: gigimazzone@yahoo.it

L. Mazzone

Department of Neuroscience, Child Neuropsychiatry Unit, IRCCS Children's Hospital Bambino Gesù, Rome, Italy

\section{Vassena}

Department of Biological and Technological Research (DIBIT), San Raffaele Scientific Institute, Milan, Italy

O. Galesi · M. Fichera

Laboratory of Genetics Diagnosis, IRCCS Oasi SS Maria,

Troina, Italy

\section{Introduction}

Brachidactyly-Mental Retardation (BDMR) Syndrome (MIM 600430), also known as Albright hereditary osteodistrophy-like syndrome (AHO-like), is a complex disorder characterized by craniofacial and skeletal abnormalities, including short stature, round face, shortened metacarpals, metatarsals and phalanges, and mental retardation (Wilson et al. 1995). In a number of studies, BDMR has been associated with chromosome deletions involving the 2q37 region (Phelan et al. 1995; Aldred et al. 2004; Shrimpton et al. 2004; Falk and Casas 2007; Felder et al. 2009) and, more recently, Williams and colleagues have better refined the critical region, reducing the candidate genes from $>20$ to a single gene, histone deacetylase 4 (HDAC4), and inferring that haploinsufficiency of HDAC4 results in BDMR syndrome (Williams et al. 2010). Deletions at chromosome 2q37 have also been associated with delays in social skills, hyperactivity, rocking movements and psychomotor retardation (Conrad et al. 1995), as well as with the occurrence of self-stimulatory or ritualistic behaviors, reciprocal social interactions and repetitive or stereotyped behaviors and interests, manifestations that could drive to a diagnosis of autistic disorder (Friedman et al. 1997; Aldred et al. 2004; Felder et al. 2009; Burd et al. 1988; Stein et al. 1992; Fisher et al. 1994; Smith et al. 2001; Reddy 2005), suggesting that the $2 \mathrm{q} 37$ deletion might be responsible for the autistic phenotype (Burd et al. 1988).

Furthermore, the coexistence of mental retardation and autism, two conditions that are strongly associated (80\% of autistic patients also show cognitive impairment), has been described also in children with 2q37 deletion (Ghaziuddin and Burmeister 1999). More recently, Aldred and colleagues further confirmed this association in a more representative sample, describing that 7 out of 20 patients with 
Table 1 Summary of published studies investigating the association between 2q37 deletion, brachydactyly mental retardation (BDMR) Syndrome and autism spectrum disorders (ASDs)

\begin{tabular}{|c|c|c|c|c|c|}
\hline Study & Type of study & $\begin{array}{l}2 \mathrm{q} 37 \\
\text { deletion }\end{array}$ & BDMR Syndrome & ASDs & Findings \\
\hline $\begin{array}{l}\text { Burd et al. } \\
\text { (1988) }\end{array}$ & Case report & Yes & $\begin{array}{l}\text { Mental and } \\
\text { developmental } \\
\text { retardation }\end{array}$ & $\begin{array}{r}\text { Infantile } \\
\text { autism }\end{array}$ & $\begin{array}{l}\text { Patient with } 2 \text { q37-qter deletion showing mental } \\
\text { and developmental retardation, associated with } \\
\text { infantile autism }\end{array}$ \\
\hline $\begin{array}{l}\text { Conrad } \\
\text { et al. } \\
(1995)\end{array}$ & Two children & Yes & N/A & N/A & $\begin{array}{l}\text { Development delay, macrocephaly, frontal } \\
\text { bossing, depressed nasal bridge and cardiac } \\
\text { anomaly, hypotonia and repetitive behavior. }\end{array}$ \\
\hline $\begin{array}{l}\text { Wilson } \\
\text { et al. } \\
(1995)\end{array}$ & Five patients & Yes & $\begin{array}{l}\text { Brachymetaphalangia } \\
\text { and mental } \\
\text { retardation }\end{array}$ & N/A & $\begin{array}{l}\text { In five unrelated patients with overlapping } \\
\text { deletions at the chromosome } 2 \mathrm{q} 37 \text { showing } \\
\text { brachymetaphalangia and mental retardation }\end{array}$ \\
\hline $\begin{array}{l}\text { Friedman } \\
\text { et al. } \\
\text { (1997) }\end{array}$ & Eight cases & Yes & Developmental delay & $\begin{array}{l}\text { Behavioral } \\
\text { problems } \\
\text { with autistic } \\
\text { features }\end{array}$ & $\begin{array}{l}\text { In eight case } 2 \mathrm{q} 37 \text { deletions were associated with } \\
\text { developmental delays and behavioral problems } \\
\text { with autistic symptoms }\end{array}$ \\
\hline $\begin{array}{l}\text { Ghaziuddin } \\
\text { et al. } \\
\text { (1999) }\end{array}$ & Two children & Yes & N/A & Yes & $\begin{array}{l}\text { Deletion of the distal portion of the long arm of } \\
\text { chromosome } 2(2 \mathrm{q} 37) \text { possibly associated with } \\
\text { autism and with a distinct phenotype }\end{array}$ \\
\hline $\begin{array}{l}\text { Smith et al. } \\
\text { (2001) }\end{array}$ & Case report & Yes & N/A & $\begin{array}{l}\text { Autistic } \\
\text { disorder }\end{array}$ & $\begin{array}{l}\text { One patient with } 2 \mathrm{q} 37 \text { deletion meeting criteria } \\
\text { for autistic disorder }\end{array}$ \\
\hline $\begin{array}{l}\text { Aldred et al. } \\
\text { (2004) }\end{array}$ & $\begin{array}{l}\text { Molecular analysis of } \\
20 \text { patients with } \\
2 \text { q37.3 monosomy }\end{array}$ & Yes & $\begin{array}{l}\text { Moderate } \\
\text { developmental delay }\end{array}$ & $\begin{array}{l}\text { Autism or } \\
\text { repetitive, } \\
\text { hyperkinetic } \\
\text { behaviors in } \\
7 \text { cases }\end{array}$ & $\begin{array}{l}\text { Narrowing of the minimal region associated with } \\
\text { patients with facial dysmorphism and } \mathrm{AHO}- \\
\text { like syndrome to } 3 \mathrm{Mb} \text {; } \\
\text { Considerate clinical variability, including autism }\end{array}$ \\
\hline $\begin{array}{l}\text { Casas et al. } \\
\text { (2004) }\end{array}$ & $\begin{array}{l}\text { Six new patients plus } \\
60 \text { previously } \\
\text { reported }\end{array}$ & Yes & $\begin{array}{l}\text { Developmental delay/ } \\
\text { mental retardation } \\
(89 \%)\end{array}$ & $\begin{array}{l}\text { Autistic } \\
\text { behavior } \\
(24 \%)\end{array}$ & $\begin{array}{l}\text { Metanalysis to try to identify phenotype- } \\
\text { breakpoints correlations in } 66 \text { individuals with } \\
\text { 2q terminal deletions }\end{array}$ \\
\hline $\begin{array}{l}\text { Shrimpton } \\
\text { et al. } \\
\text { (2004) }\end{array}$ & $\begin{array}{l}\text { Three patients with } \\
\text { Albright hereditary } \\
\text { osteodystrophy } \\
\text { (AHO) }\end{array}$ & Yes & $\begin{array}{l}\text { Mild to moderate } \\
\text { mental retardation }\end{array}$ & Yes & $\begin{array}{l}\text { Narrowing of the deletion region to } 3 \mathrm{Mb} \text {, and } \\
\text { identification of the G-protein-coupled recepto } \\
35 \text { (GPR35) as a putative gene involved in the } \\
\text { syndrome }\end{array}$ \\
\hline $\begin{array}{l}\text { Felder } \\
(2009)\end{array}$ & Case report & $\begin{array}{l}\text { 2q37 } \\
\text { deletion } \\
\text { syndrome }\end{array}$ & BDMR Syndrome & Yes & $\begin{array}{l}\text { Downregulation of three genes: FERM, RhoGEF } \\
\text { and pleckstrin domain protein } 2 \text { (FARP2), } \\
\text { glypican } 1 \text { (GPC1), vigilin (HDLBP), kinesin } \\
\text { family member 1A (KIF1A) and proline- } \\
\text { alanine-rich STE20-related kinase (PASK), } \\
\text { involved in skeletal or neural differentiation } \\
\text { processes }\end{array}$ \\
\hline
\end{tabular}

NA not applicable

2 q37 monosomy (35\%) also showed autism or repetitive hyperkinetic behaviors (Aldred et al. 2004).

Studies investigating the association between 2 q37 deletions and BDMR and/or autism spectrum disorders (ASDs) and corresponding findings are summarized in Table 1.

However, most of these papers reported only on repetitive or self stimulatory behaviors and no more specific behavioral description is provided; moreover, only in very few cases the diagnosis of autism was made according to the defined criteria and/or using standardized diagnostic instruments, including follow-up evaluations.

In the present study we describe the occurrence of autism in two unrelated children with de novo del (2)(q37 $\rightarrow$ qter) associated with BDMR and the evolutionary course of the autistic behaviors over a follow-up period of 5 years.

\section{Procedures}

Both patients received physical, genetic and repeated cognitive and behavioral assessments. The Autism Diagnostic Interview-Revised (ADI-R) (Lord et al. 1994), the Autism Diagnostic Observation Schedule (ADOS) (Lord et al. 2000b) and the Childhood Autism Rating Scale (CARS) (Schopler et al. 1980) were administered to both patients. The scoring on the ADOS and CARS was based 
on observations and video-recordings of the children in both structured and non-structured situations and took from 30 to $60 \mathrm{~min}$ for each child. Inter-rater reliability between the assessors on the use of the ADI-R, ADOS and CARS averaged $87 \%$. A cognitive testing was also carried out, administering the Leiter International Performance ScaleRevised (Roid GH 1997).

\section{Patients}

Two patients showing BDMR were included in the present report. Patient 1 is a 4 year-old boy referred for developmental delay, and for social, behavioral, facial and physical abnormalities. Patient 2 is a 3 year- 4 month-old girl referred for developmental delay, social, behavioral, facial and physical abnormalities, simple and complex febrile and afebrile seizures. Early motor and language milestones were delayed in both patients. Their physical features were also peculiar. The boy was characterized by frontal bossing with forehead narrowing, deep-set eyes, strabismus, narrow palpebral fissures, thin arched and laterally displaced eyebrows, nose with depressed root, hypoplastic alae and bulbous tip, flat philtrum, thin upper lip, small and low set ears, short neck, slight brachydactyly of the III-IV metacarpal bones, joint hyperlaxity, truncal hypotonia, kyphoscoliosis, ataxia, clumsiness and nasal voice. The girl showed forehead with lateral hyperthricosis, upslanting palpebral, thin arched and laterally displaced eyebrows, depressed nasal root, hypoplastic alae, short philtrum, prominent columella fissures, thin upper lip, large ears, brachydactyly of the IV metacarpal bone. The patient had diffuse hypotonia, ataxia, clumsiness, joint laxity and nasal voice.

By clinical observations they both showed the following autistic symptoms, in line with the DSM IV criteria: impairment in social interaction with abnormal eye-to-eye contact, lack of spontaneous seeking to share enjoyment or interests with other people (i.e. interest in simple social games), and repetitive motor mannerisms with a restricted pattern of interests and an apparently inflexible adherence to specific non-functional routines or rituals (persistent fascination for circular objects). Disruptive behavior, self-injury, aggression, hyperactivity and tantrums, were also present.

\section{Main Laboratory Findings}

\section{Cytogenetic Studies}

Chromosomal analysis of G-banded metaphases showed 46,XY, del(2)(q37 $\rightarrow$ qter)dn. Array CGH analysis performed using a custom-made Human Genome CGH Microarray 44A Kit (Agilent Technologies, Palo Alto, CA, USA) confirmed in chromosome 2q37.2 a subtelomeric deletion in both patients.
Patient 1 showed a deletion of about 7.2 Mb with centromeric breakpoint between 235,335,566 and 235,409,163 bp and contained also a subtelomeric duplication of about $2.6 \mathrm{Mb}$ in $18 \mathrm{q} 23$ with centromeric breakpoint between $73,349,085$ and 73,433,861 bp (NCBI Build 36.1). In patient 2 a subtelomeric deletion of about $5.2 \mathrm{Mb}$ was detected, with centromeric breakpoint between 236,850,460 and 236,926,103 bp (NCBI Build 36.1).

Brain MRI examination in patient 1 showed mild involution changes in the parietal region greater than expected for age. Besides this, the picture was overall normal. In patient 2 brain MRI examination revealed caudal displacement of the cerebellar tonsils through the cervical canal. Inter-ictal EEG recordings during wakefulness and sleep showed normal background activity.

\section{Behavioral Assessment and Follow-Up}

Table 2 summarizes the scores on ADI-R, ADOS, CARS scales for autism and on the Leiter-R full IQ scale for both patients, measured at five subsequent evaluations to cover a overall period of 5 years. As indicated by the reduction of the score values, a progressive decrease of the autistic spectrum symptoms and behaviors, as well as an increase in the IQ value, albeit slight, was documented in both patients. These results are also shown in Fig. 1, in which ADI-R subscales and ADOS and CARS total scores over time are presented separately for patient 1 and patient 2 (Fig. 1a, b), as well as the Leiter IQ results for both patients performed at the last three evaluations (Fig. 1b).

At the time of the first examination (4 years of age for the boy and 3 years and 6 months for the girl) both patients showed symptoms and behaviors falling into the autistic spectrum and they both met the cut-off criteria for autistic disorder, as indicated by the ADI-R and ADOS scores (Table 2; Fig. 1a). CARS scores were respectively 46 for the boy and 50 for the girl, indicating severe autism (Table 2; Fig. 1a) and, in line with this, the diagnosis according to DSM-IV-TR was autistic disorder.

At the second evaluation, both patients showed decreased scores in social interactions, sharing attention and interest, ability to imitate simple movements and purposeful use of objects. Moreover, a reduction in ritualistic and repetitive behaviors as well as in the use of stereotyped and repetitive language were also observed, together with a more generalized amelioration in the ability to communicate nonverbally. Disruptive behaviors, self-injury, aggression, hyperactivity and tantrums were also reduced. These changes were reflected in a reduction of the ADI-R, ADOS and CARS scores, as shown in Table 2 and Fig. 1a.

At the third follow-up the behavioral patters were even better, with reciprocal social interaction and spontaneous imitation showing the biggest improvement, followed by 
Table 2 Autistic and cognitive evaluation for patients 1 and 2 over a period of 5 years ( 5 follow-up evaluations)

\begin{tabular}{|c|c|c|c|c|c|c|c|}
\hline \multirow{3}{*}{$\begin{array}{l}\text { Table } 2 \text { Autistic and cognitive } \\
\text { evaluation for patients } 1 \text { and } 2 \\
\text { over a period of } 5 \text { years ( } 5 \\
\text { follow-up evaluations) }\end{array}$} & \multirow[t]{2}{*}{ Parameter } & \multirow[t]{2}{*}{ Patient* } & \multicolumn{5}{|c|}{ Follow-up evaluation } \\
\hline & & & First & Second & Third & Fourth & Fifth \\
\hline & \multirow[t]{2}{*}{ Child age } & 1 & 4 years & 5 years & 6 years & 7 years & 9 years \\
\hline & & 2 & $\begin{array}{l}3 \text { years, } \\
6 \text { month }\end{array}$ & $\begin{array}{l}4 \text { years } \\
2 \text { month }\end{array}$ & 5 years & 6 years & 8 years \\
\hline & \multicolumn{7}{|l|}{$\mathrm{ADI}-\mathrm{R}$ items } \\
\hline & \multirow[t]{2}{*}{ Social interaction } & 1 & 24 & 15 & 12 & 6 & \\
\hline & & 2 & 27 & 24 & 19 & 10 & \\
\hline & \multirow[t]{2}{*}{ Communication } & 1 & 12 & 9 & 7 & 6 & \\
\hline & & 2 & 15 & 12 & 11 & 10 & \\
\hline & \multirow[t]{2}{*}{ Repetitive behaviors } & 1 & 6 & 5 & 4 & 3 & \\
\hline & & 2 & 9 & 7 & 6 & 5 & \\
\hline & \multicolumn{7}{|l|}{ ADOS items } \\
\hline & \multirow{2}{*}{$\begin{array}{l}\text { Language and } \\
\text { communication }\end{array}$} & 1 & 9 & 6 & 4 & 2 & \\
\hline & & 2 & 10 & 9 & 7 & 7 & \\
\hline & \multirow[t]{2}{*}{ Social interaction } & 1 & 14 & 10 & 8 & 5 & \\
\hline & & 2 & 14 & 12 & 10 & 9 & \\
\hline & \multirow[t]{2}{*}{ ADOS total } & 1 & 23 & 16 & 12 & 7 & \\
\hline & & 2 & 24 & 21 & 17 & 16 & \\
\hline & \multirow[t]{2}{*}{ CARS total } & 1 & 46 & 35 & 32 & 30 & \\
\hline & & 2 & 50 & 46.5 & 43 & 40.5 & \\
\hline & \multirow[t]{2}{*}{ Leiter IQ } & 1 & & & 40 & 40 & 42 \\
\hline $\begin{array}{l}\text { Patient } 1 \text { is a boy, patient } 2 \text { is } \\
\text { a girl }\end{array}$ & & 2 & & & 35 & 38 & 40 \\
\hline
\end{tabular}

* Patient 1 is a boy, patient 2 is a girl the use of object and eye contact, and disruptive behaviors, self-injury, tantrums and unusual sensory interests almost disappearing. Mirroring the behavioral manifestations, ADI-R, ADOS and CARS scores were also greatly improved (Table 2; Fig. 1a). Particularly, CARS scores dropped from 50 to 43 for the girl (still indicating severe autism), and from 46 to 32 for the boy (indicating mild-moderate autism), whose diagnosis according to DSM-IV-TR was at this point Pervasive Developmental Disorder-Not Otherwise Specified.

An additional follow up examination was performed for the girl, who ultimately showed an appropriate emotional and social response, as well as reduced stereotyped, repetitive language and idiosyncratic spoken language.

The Leiter-R full IQ scale was administered for the first time to the boy at 6 years old and to the girl at 5 years old, revealing scores of 40 and 35, corresponding to moderate and severe mental retardation, respectively (Table 2; Fig. 1b). A second evaluation of the IQ was performed after two additional years, when the boy and the girl were 9 and 8 years old, and showed an IQ of 42 and 40, respectively, indicating moderate mental retardation (Table 2; Fig. 1b).

\section{Treatment}

During the 5 year-follow-up period, both patients received a matched treatment focused primarily on speech and psychomotory therapy, performed 4 times a week in an official rehabilitation center in Catania. The boy also attended once a week for 1 year a supplementary cognitive-behavioral therapy with a private therapist, and received the Picture Exchange Communication System (PECS) to improve his communication skills.

None of them received any type of pharmacological treatment during the study period.

\section{Discussion}

The aim of the present work was to describe the occurrence and evolutionary course of the autistic behaviors in two unrelated children with de novo 2 q37 $\rightarrow$ qter deletion associated with BDMR. Both children shared similar facial and physical features at the first examination. They both displayed symptoms falling into the autistic spectrum phenotype, and they both met the cut-off criteria for Autistic Disorder on the ADI-R and ADOS; CARS global score also indicated severe autism. During a follow-up period of approximately 3 years they were evaluated -on average- once every 8.8 months ( 3 times for patient 1 and 4 times for patient 2). By clinical evaluation, both children showed consistent progresses on the different aspects of the autistic symptomatology and these observations were 
Fig. 1 ADI-R (Social Interaction, Comunication and Repetitive Behaviours), ADOS and CARS scores (a) for patient 1 and patient 2 at 4 longitudinal evaluations. (b) Leiter IQ scores for patient 1 and 2 at three longitudinal evaluations. Patient 1 is a boy, patient 2 is a girl
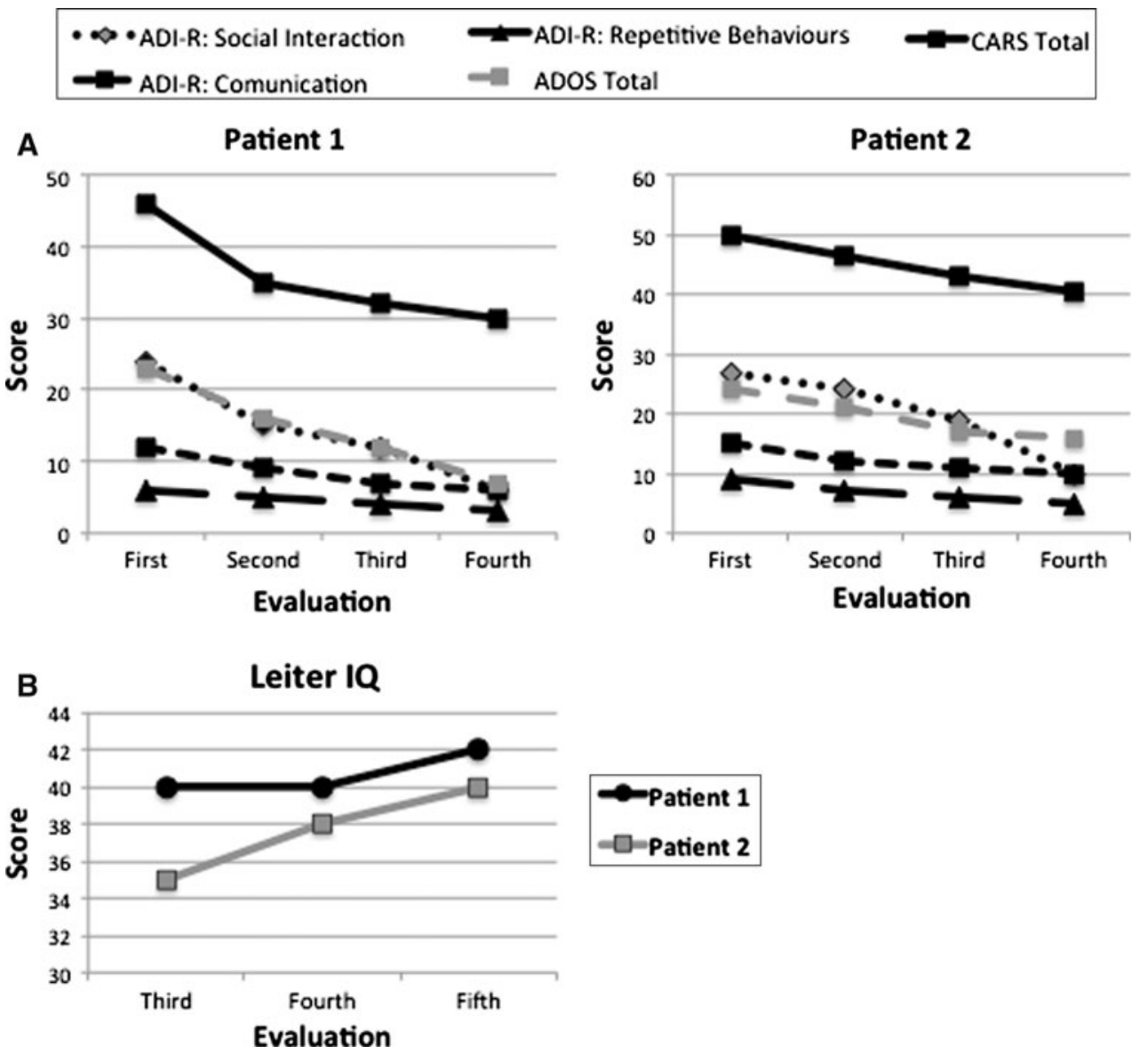

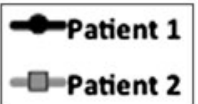

confirmed by a reduction in the scores of all the three measures used (ADI-R, ADOS and CARS).

These results suggest that patients with $2 \mathrm{q} 37$ deletion associated with BDMR could have a peculiar evolutionary clinical course of the autistic behavior and symptoms, characterized by a progressive improvement as the months elapse, over a period of several years during childhood. By contrast, evidences suggest that most diagnoses of autism are stable from age 2 years onward and developmental changes in ADSs, when occurring, are not always linear (Volkmar et al. 2004).

The association of $2 \mathrm{q} 37$ deletion with autism has already been investigated by several studies, starting from Stein et al. (1992), and since then additional studies have reported the presence of symptoms overlapping with the autism spectrum in patients with $2 \mathrm{q} 37$ deletions (Ghaziuddin and Burmeister 1999; Aldred et al. 2004; Casas et al. 2004). However, to our knowledge none of these reports investigated the evolutionary pattern of these patients. The longitudinal evaluation described herein, allowed us to identify in two unrelated patients the occurrence of a peculiar pattern of evolution for the autistic symptoms.

Of course, we have to admit that a crucial role could have been played by the speech and psychomotor therapy that both patients started since the first evaluation and that could have contributed to the observed improvement in the autistic symptoms. Indeed, several reports have shown that early intervention, including Applied Behavior Analysis (ABA) (Lovaas 1987), Early Intensive Behavioral Intervention (EIBI) (Howlin et al. 2009), and the Early Start Denver Model (ESDM) (Dawson et al. 2010), but also standard care, can improve the clinical outcome of children with ASDs and autistic children and adults can clearly benefit from direct teaching. Indeed speech and psychomotor therapy was likely to have had a certain impact on our patients, especially on the improvement of autistic symptoms. However, controversy still remains as to whether it is possible to alter the trajectory of development in a child with autism or whether early interventions simply accelerate development in children who would make good progress in response to many treatments (Lord et al. 2000a). For instance, Picture Exchange Communication System (PECS) training, which one of our patients received, was shown to enhance children's spontaneous communication for instrumental requesting using pictures and/or speech, but the effects of training were moderated by baseline factors, and PECS seemed to increase spontaneous speech in children who could talk a little at baseline (Gordon et al. 2011). 
In line with this, the observation of a better evolutionary course in patients with $2 q 37$ deletion, eventually leading to the resolution of the autistic symptoms, is extremely interesting, both for the patophysiology of the 2 q37 deletion syndrome and for the therapeutic implications. In fact, the recognition of such a peculiar pattern in a given patient could help to choose the most appropriate strategies of treatment and further supports the idea that an early treatment in this type of patients could potentially drive and accelerate their natural tendency towards symptoms resolution and achievement of social competence. Longterm follow-up evaluations and further studies, ideally including a larger number of patients are necessary to eventually confirm this theory, and to better describe the evolutionary course of the BDMR syndrome-related autistic phenotype, also in a therapeutic perspective.

\section{References}

Aldred, M. A., Sanford, R. O., Thomas, N. S., Barrow, M. A., Wilson, L. C., Brueton, L. A., et al. (2004). Molecular analysis of 20 patients with 2q37.3 monosomy: definition of minimum deletion intervals for key phenotypes. Journal of Medical Genetics, 41(6), 433-439.

Burd, L., Martsolf, J. T., Kerbeshian, J., \& Jalal, S. M. (1988). Partial $6 \mathrm{p}$ trisomy associated with infantile autism. Clinical Genetics, 33(5), 356-359.

Casas, K. A., Mononen, T. K., Mikail, C. N., Hassed, S. J., Li, S., Mulvihill, J. J., et al. (2004). Chromosome $2 q$ terminal deletion: report of 6 new patients and review of phenotype-breakpoint correlations in 66 individuals. American Journal of Medical Genetics Part A, 130A(4), 331-339.

Conrad, B., Dewald, G., Christensen, E., Lopez, M., Higgins, J., \& Pierpont, M. E. (1995). Clinical phenotype associated with terminal 2q37 deletion. Clinical Genetics, 48(3), 134-139.

Dawson, G., Rogers, S., Munson, J., Smith, M., Winter, J., Greenson, J., et al. (2010). Randomized, controlled trial of an intervention for toddlers with autism: The Early Start Denver Model. Pediatrics, 125(1), e17-e23. doi:10.1542/peds.2009-0958.

Falk, R. E., \& Casas, K. A. (2007). Chromosome 2q37 deletion: Clinical and molecular aspects. American Journal of Medical Genetics Part C, Seminars in Medical Genetics, 145C(4), 357-371.

Felder, B., Radlwimmer, B., Benner, A., Mincheva, A., Todt, G., Beyer, K. S., et al. (2009). FARP2, HDLBP and PASK are downregulated in a patient with autism and 2q37.3 deletion syndrome. American Journal of Medical Genetics Part C, Seminars in Medical Genetics, 149A(5), 952-959.

Fisher, A. M., Ellis, K. H., Browne, C. E., Barber, J. C., Barker, M., Kennedy, C. R., et al. (1994). Small terminal deletions of the long arm of chromosome 2: Two new cases. American Journal of Medical Genetics, 53(4), 366-369.

Friedman, B. D., Gorski, J., Hall, B. D., Brothman, A., Carey, J. C., \& Flejter, W. L. (1997). Deletion of chromosomal region 2q37: Clinical phenotype in eight cases. American Journal of Human Genetics, 61, A98.

Ghaziuddin, M., \& Burmeister, M. (1999). Deletion of chromosome 2q37 and autism: A distinct subtype? Journal of Autism and Developmental Disorders, 29(3), 259-263.
Gordon, K., Pasco, G., McElduff, F., Wade, A., Howlin, P., \& Charman, T. (2011). A communication-based intervention for nonverbal children with autism: What changes? Who benefits? Journal of Consulting Psychology, 79(4), 447-457. doi:10.1037/ a0024379.

Howlin, P., Magiati, I., \& Charman, T. (2009). Systematic review of early intensive behavioral interventions for children with autism. American Journal on Intellectual and Developmental Disabilities, 114(1), 23-41. doi:10.1352/2009.114:23;nd41.

Lord, C., Cook, E. H., Leventhal, B. L., \& Amaral, D. G. (2000a). Autism spectrum disorders. Neuron, 28(2), 355-363.

Lord, C., Risi, S., Lambrecht, L., Cook, E. H., Jr., Leventhal, B. L., DiLavore, P. C., et al. (2000b). The autism diagnostic observation schedule-generic: A standard measure of social and communication deficits associated with the spectrum of autism. Journal of Autism and Developmental Disorders, 30(3), 205-223.

Lord, C., Rutter, M., \& Le Couteur, A. (1994). Autism diagnostic interview-revised: A revised version of a diagnostic interview for caregivers of individuals with possible pervasive developmental disorders. Journal of Autism and Developmental Disorders, 24(5), 659-685.

Lovaas, O. I. (1987). Behavioral treatment and normal educational and intellectual functioning in young autistic children. Journal of Consulting and Clinical Psychology, 55(1), 3-9.

Phelan, M. C., Rogers, R. C., Clarkson, K. B., Bowyer, F. P., Levine, M. A., Estabrooks, L. L., et al. (1995). Albright hereditary osteodystrophy and del(2) (q37.3) in four unrelated individuals. American Journal of Medical Genetics, 58(1), 1-7.

Reddy, K. S. (2005). Cytogenetic abnormalities and fragile-X syndrome in autism spectrum disorder. BMC Medical Genetics, $6,3$.

Roid GH, M. L. (1997). Leiter international performance scalerevised edition. Wood Dale, IL: Stoelting Co.

Schopler, E., Reichler, R. J., DeVellis, R. F., \& Daly, K. (1980). Toward objective classification of childhood autism: Childhood autism rating scale (CARS). Journal of Autism and Developmental Disorders, 10(1), 91-103.

Shrimpton, A. E., Braddock, B. R., Thomson, L. L., Stein, C. K., \& Hoo, J. J. (2004). Molecular delineation of deletions on 2q37.3 in three cases with an Albright hereditary osteodystrophy-like phenotype. Clinical Genetics, 66(6), 537-544.

Smith, M., Escamilla, J. R., Filipek, P., Bocian, M. E., Modahl, C., Flodman, P., et al. (2001). Molecular genetic delineation of 2q37.3 deletion in autism and osteodystrophy: Report of a case and of new markers for deletion screening by PCR. Cytogenetics and Cell Genetics, 94(1-2), 15-22.

Stein, C. K., Del Signore, C., Bellinger, M., \& Bryke, C. R. (1992). Deletion of 2q37-a new syndrome? American Journal of Human Genetics, 51, A308.

Volkmar, F. R., Lord, C., Bailey, A., Schultz, R. T., \& Klin, A. (2004). Autism and pervasive developmental disorders. Journal of Child Psychology and Psychiatry, 45(1), 135-170.

Williams, S. R., Aldred, M. A., Der Kaloustian, V. M., Halal, F., Gowans, G., McLeod, D. R., et al. (2010). Haploinsufficiency of HDAC4 causes brachydactyly mental retardation syndrome, with brachydactyly type E, developmental delays, and behavioral problems. American Journal of Human Genetics, 87(2), 219-228.

Wilson, L. C., Leverton, K., Oude Luttikhuis, M. E., Oley, C. A., Flint, J., Wolstenholme, J., et al. (1995). Brachydactyly and mental retardation: An Albright hereditary osteodystrophy-like syndrome localized to 2q37. American Journal of Human Genetics, 56(2), 400-407. 